IZA DP No. 124

Rational Poverty or Poor Rationality? The Take-up of Social Assistance Benefits

Regina T. Riphahn

March 2000 


\title{
Rational Poverty or Poor Rationality? The Take-up of Social Assistance Benefits
}

\author{
Regina T. Riphahn \\ University of Munich, CEPR, London and IZA, Bonn, Germany
}

\author{
Discussion Paper No. 124 \\ March 2000
}

\author{
IZA \\ P.O. Box 7240 \\ D-53072 Bonn \\ Germany \\ Tel.: +49-228-3894-0 \\ Fax: +49-228-3894-210 \\ Email: iza@iza.org
}

This Discussion Paper is issued within the framework of IZA's research area The Welfare State and Labor Markets. Any opinions expressed here are those of the author(s) and not those of the institute. Research disseminated by IZA may include views on policy, but the institute itself takes no institutional policy positions.

The Institute for the Study of Labor (IZA) in Bonn is a local and virtual international research center and a place of communication between science, politics and business. IZA is an independent, nonprofit limited liability company (Gesellschaft mit beschränkter Haftung) supported by the Deutsche Post AG. The center is associated with the University of Bonn and offers a stimulating research environment through its research networks, research support, and visitors and doctoral programs. IZA engages in (i) original and internationally competitive research in all fields of labor economics, (ii) development of policy concepts, and (iii) dissemination of research results and concepts to the interested public. The current research program deals with (1) mobility and flexibility of labor markets, (2) internationalization of labor markets and European integration, (3) the welfare state and labor markets, (4) labor markets in transition, (5) the future of work, (6) project evaluation and (7) general labor economics.

IZA Discussion Papers often represent preliminary work and are circulated to encourage discussion. Citation of such a paper should account for its provisional character. 


\section{ABSTRACT \\ Rational Poverty or Poor Rationality? The Take-up of Social Assistance Benefits}

In several countries social assistance dependence has been increasing since the 1980s. After surveying the theoretical and empirical take-up literature, this study presents estimates of recent rates of non take-up of social assistance benefits. Once methodological shortcomings of prior estimations are corrected, the results show that take-up has fallen recently and thus cannot explain the rising welfare receipt. Following theoretical predictions, the probability that a rational individual takes up social assistance increases with the expected benefit amount and duration, and falls with application cost and stigma. More than half of all households eligible for transfers under the German social assistance program did not claim their benefits.

JEL Classification: I38, I32, D31

Keywords: Take-up, transfer program, social assistance, welfare

Regina T. Riphahn

University of Munich

Ludwigstr. $28 \mathrm{RG}$

80539 Munich

Germany

Tel.: $+49-89-21802128$

Fax: +49 - 89 - 336392

Email: regina.riphahn@selapo.vwl.uni-muenchen.de

\footnotetext{
*I thank Jennifer Hunt for very helpful comments on an earlier version of this paper.
} 


\section{Introduction}

Recently the issue of benefit take-up in public transfer programs has received increasing attention in economic research (e.g. Anderson and Meyer 1997, Duclos 1995, Yaniv 1997). At first sight, it appears counter to the predictions of economic theory that individuals would not collect benefits available to them. Yet, van Oorschot (1994) cites evidence of at least 20 percent non take-up rates in state transfer programs, and others point to even higher rates. The study of take-up behavior is driven by an interest in explaining this economic puzzle.

In addition, investigations of take-up address at least four important questions. First, rising take-up rates over time may explain part of the upsurge in welfare receipt, observed in numerous countries over the last decades (OECD 1998a, 1998b). Second, if transfer programs are administered in a way which deters individuals from using them, the programs may fail to reach their objectives. In the case of poverty alleviation, this can have dramatic effects for the wellbeing of the poor. Third, if social assistance programs effectively eliminate poverty when transfers are received, then the rate of non take-up provides a relevant measure of post-transfer poverty. Fourth and from a different perspective, estimates of take-up rates are important information when calculating potential expenditure effects of policy reforms.

The international literature provides various theoretical modelling approaches for take-up behavior and has empirically investigated the role of economic incentives in the take-up decision for a number of transfer programs. Prior contributions on take-up in the German social assistance program only evaluated take-up rates at different points in time in a descriptive manner. This study extends the literature in four important ways: First, it is the first to empirically test hypotheses explaining the puzzling non take-up behavior for Germany. Second, following Duclos (1995), who draws attention 
to the issue of measurement error in take-up studies, it improves on prior methods of calculating the rate of non take-up. Several shortcomings of past take-up calculations are pointed out, and sensitivity analyses show that their effects are major. With the corrected methodology, the population share of households not taking up their benefits is only half that found in prior studies. Third, while almost the entire literature on non take-up in the social assistance program is based on data from the 1960s and 1970s, this study applies more recent data from 1993. The data from the German Income and Expenditure Survey (EVS, Einkommens- und Verbrauchsstichprobe), is highly suitable for this purpose since it provides precise information on household finances for over 40,000 households. In addition, the 1993 wave of the EVS is the first to also consider East German and foreign households. Finally, this paper provides a comprehensive survey of research on non take-up in general, and for the German social assistance program in particular.

In contrast to Anglosaxon terminology, in this study a household is considered to be poor if low income and wealth ownership render it eligible for social assistance benefits (detailed eligibility conditions are described below). German government language maintains that households, who receive social assistance transfers, are no longer poor, as their poverty is fought off through transfers. However, households remain in "hidden poverty" if they are eligible for social assistance benefits, but "hide" their poverty by not taking up social assistance. Thus it is "hidden poverty" that is of principal interest in this study.

The main findings are threefold: First, non take-up in the German income support program has increased to about 60 percent of the eligible households. Therefore the observed increase in welfare receipt reflects a real change in the underlying income distribution, rather than a mere adjustment in take-up behavior. Second, estimation results confirm the theoretically predicted impact of benefit 
amounts, of the expected duration of benefit payments, and of application costs and stigma effects on take-up decisions. Finally, transfer payments would increase by more than 16 percent, were all eligible households to take up their benefits.

The paper first reviews the international literature and prior German contributions on take-up in sections two and three. It then briefly describes the institutional framework of the social assistance program in section four. Next, the data and the procedure used to calculate take-up rates are discussed. Section six presents an empirical analysis of the determinants of non take-up and the paper concludes with a summary of the main findings and a discussion of policy implications in section seven.

\section{Modelling Take-up Behavior}

The determinants of benefit take-up in transfer programs have been on the agenda of economic research for a long time (for early contributions see Moffitt 1983, or Ashenfelter 1983), but a more intense discussion of the subject took place only recently (for surveys see Craig 1991, or van Oorschot 1991). The literature provides participation studies for various U.S. and U.K. transfer programs: Blank and Ruggles (1996) study take-up in U.S. welfare programs; Anderson and Meyer (1997), Blank and Card (1991), and McCall (1995) focus on participation in the U.S. unemployment insurance; Fry and Stark (1989) and Duclos (1995) investigate take-up in the U.K. Supplementary Benefit program, Atkinson (1989) reviews take-up of U.K. one-parent benefits and family income support, Kim and Mergoupis (1997) evaluate participation in the U.S. food stamp program, and Blundell et al. (1988) review the case of the U.K. housing benefit program. While not all of these studies provide a theoretical model to derive their hypotheses, among those who do, static and dynamic approaches to describe the program participation decision can be distinguished. 
Examples of a static approach are Moffitt (1983), Blundell et al. (1988), and Yaniv (1997). Yaniv (1997) sets up a utility maximizing framework where utility depends positively on income and negatively on the number of weeks worked. Individuals choose the optimal number of weeks to work, given that income can also be received as a transfer. The optimality condition states that the person should participate in the program until the marginal disutility of work equals the stigma adjusted effective benefit (SAEB) per week of participation. SAEB increases with benefits, and declines with the degree of discomfort and of work requirement in the welfare program. Based on this theoretical analysis, Yaniv concludes that stigma might well constitute a stronger deterrent to participation than an expected penalty for dishonest claiming.

In contrast to Yaniv, Moffitt (1983) and Blundell et al. (1988) present empirical tests of their theoretical approaches. Moffitt (1983) allows stigma to affect utility either as a constant factor connected to program participation, or as a factor which varies with the benefit amount. The model yields testable hypotheses on the effects of marginal income tax rates, of wages, hours worked, nonwage income, and benefit levels. Moffitt estimates a two equation model for leisure demand and program participation, and concludes that stigma is appropriately represented by a fixed factor of disutility.

In the model of Blundell et al. (1988) stigma effects and application costs are not parameters in the utility function - as in Moffitt's setting - but considered in an explicit cost function, which imposes a fixed stigma effect. Whereas Moffitt derives the functional form of the estimated indirect utility function from a labor supply model, Blundell et al. formulate linear approximations to the utility and cost functions. The participation probability equals the probability that the utility difference when participating vs. when not participating exceeds the application and stigma cost. It can be 
approximated by a linear combination of relevant factors, such as the benefit amount, prior income, and sociodemographic characteristics. While the authors cannot rigorously derive hypotheses from their theoretical model, they posit plausibly that the higher the benefit the higher the chance of compensating for the fixed stigma cost of participation. This reasoning is confirmed in their empirical analysis.

Anderson and Meyer (1997) extend the static models by explicitly considering the impact of the expected duration of (unemployment) benefit receipt in the individual participation decision. An individual will take up benefits if over the expected length of an unemployment spell the utility difference with and without benefits exceeds the cost of take-up. The utility difference is determined by the expected benefit duration and amount. Based on the optimality condition for benefit take-up, a number of hypotheses are derived: Higher benefits, lower take-up costs, and a longer benefit duration are expected to increase the probability of program participation. Anderson and Meyer test these predictions and find that a 10 percent increase in benefits would raise take-up by about 2 percentage points, and a 10 percent longer benefit duration would increase participation probabilities by about one percentage point. The theoretical framework of Anderson and Meyer is adopted here to guide the empirical analysis.

\section{The German Literature}

In contrast to the international literature on take-up behavior, German studies provide mostly descriptive evidence on the magnitude, sociodemographic distribution, and potential explanations of non take-up. The contributions on "hidden poverty", i.e. non take-up of income support benefits, are surveyed by Adam (1977), Schulz (1989), and Neumann and Hertz (1998). I focus on studies, which 
generated nationally representative results (summarized in Table 1). ${ }^{1}$

Early results on poverty in 1970s Germany are presented by Kortmann (1978) and Klanberg (1979). Their calculations are based on the most frequently applied dataset in German poverty studies, the EVS (Income and Expenditure Survey). Kortmann (1978) finds an overall poverty rate of 0.7 percent for 1969. Klanberg (1979) evaluated the 1969 and 1973 EVS surveys and, depending on the calculation method, finds poverty rates between 1.1 and 5.1 percent for households in 1969 and between 1.6 and 4.6 percent in 1973.

An influential study was that of Transfer-Enquête-Kommission (1981), a government commission studying the impact of public transfers on household incomes. The commission based its estimates on the 1973 wave of the EVS, and concluded that of the 350,000 German households who had pre-transfer incomes below the income support level, about one third lived in hidden poverty. It estimated the amount by which those in hidden poverty remained below the income support minimum income: This poverty gap amounted to on average between 5 and 10 percent of the income support benefit. Three main reasons for non take-up of benefits were identified: (i) ignorance about the program, (ii) misconceptions about eligibility conditions, and (iii) fear of causing problems with family relations, who might have to reimburse the social assistance administration for the transfers to their relatives.

Hauser et al. (1981) took advantage of three waves of comparable EVS data and presented poverty rate calculations for the years 1963,1969 , and 1973 . They found that the rate of poverty declined between 1963 and 1969, but increased again in 1973. The authors explain that the social

\footnotetext{
${ }^{1}$ Additional contributions are surveyed in Riphahn (1999).
} 
assistance minimum income was particularly low in $1969,{ }^{2}$ which leaves a smaller fraction of the population with incomes below that minimum, and poverty rates artificially depressed. Hidden poverty apparently decreased from about 60 percent of all poor households in 1963, to about 50 percent in the later years. It is particularly frequent among those not in the labor force, and among elderly single women. Hauser et al. (1981) show that hidden poor households fall on average 16 (13) percent short of the minimum income in 1969 (1973), exceeding the levels calculated by the Transfer-EnquêteKommission (1981).

Hartmann's 1985 study is based on data from a representative survey of 25,000 households, gathered in 1979. His results confirm the figures presented by Hauser et al. (1981): He considers about five percent of the population to be poor, and of these 48 percent are in hidden poverty, suggesting that the situation did not change much after 1973. Hartmann confirms that the poor population mostly consists of female elderly individuals and points to the concentration of the hidden poor in rural areas. Unfortunately, he provides no information as to how he calculated incomes and whether he considered wealth in determining eligibility. Similarly brief is the discussion provided in Hauser and Semrau (1990). The authors applied EVS data from 1983, and found a non take-up rate of about 30 percent. This indicates a significant decline from the last available measure of 48 percent, as measured by Hartmann (1985) for 1979.

Neumann and Hertz (1998) provide the latest representative study on non take-up and hidden poverty, using the German Socioeconomic Panel (GSOEP), an individual and household level dataset, to measure hidden poverty in 1991 and 1995 . This is the first study to consider East German and foreign households in addition to the West German population. Again, no correction for wealth

\footnotetext{
${ }^{2}$ For a discussion of the determination of social assistance minimum income see section 4 below.
} 
ownership is considered in the determination of benefit eligibility. Neumann and Hertz calculate that about 3 million individuals live in hidden poverty, with the overall rate declining from 3.7 to 3.4 percent of the population between 1991 and 1994. The decline is due to a drop in East German rates of hidden poverty from 5.6 to 4.2 percent, while the West German rates remained constant at 3.2 percent. Hidden poverty is much higher among foreign than native households. The authors show that the average hidden poor West (East) German household fell about 18.3 (19.7) percent short of the minimum income. The high non take-up figures for East Germany as of 1991 might be explained by the fact that the social assistance administration there was barely functioning when the interviews took place. Relating the number of hidden poor individuals to the officially registered income support beneficiaries, yields shares of about 59 and 52 percent of non take-up. Relative to the measure of Hauser and Semrau (1990) based on 1983 data, this represents a steep increase in hidden poverty. I investigate below whether this increase can be confirmed using the 1993 EVS data.

\section{A Brief Introduction to the German Social Assistance Program}

\subsection{General Features}

The German social assistance program consists of two parts, income support (Hilfe zum Lebensunterhalt) and support for special circumstances (Hilfe in besonderen Lebenslagen). The purpose of the income support system is to guarantee that every resident can lead a 'dignified' life based on a socio-culturally determined minimum income. Generally, every individual with less than this minimum income must be financially supported, in order to enable the recipient to participate in community life and to regain economic independence. Support for special circumstances is intended for individuals, who might be able to meet their subsistence needs, but who are unable to care for their 
special needs. The law lists 13 such circumstances when the social assistance administration might become involved. The most frequently occurring ones are related to support for the handicapped, for long-term care, and for health care.

Income support and support for special circumstances differ in that the income support system typically uses standardized payments. Given the variety of needs covered by support for special circumstances, these benefits are individualized. Also, the means tests regarding disposable income and property are more lenient in the case of support in special circumstances than for income support.

As of 1998 the income support part of the pogram accounted for 46 percent and support in special circumstances for 54 percent of total social assistance expenditures. Real expenditures on income support grew by 29 percent between 1994 and 1998. Total expenditures for social assistance as a fraction of GDP increased from .5 percent in 1970 to about 1.5 percent in the nineties. The number of West German income support recipients rose from 0.92 million in 1980, to 1.8 in 1990, and 2.5 million in 1998, when 3.7 percent of the population were supported (2.7 percent in East Germany, cf. STBA 1999)

\subsection{Benefits and Eligibility Conditions}

In the case of income support, four types of financial benefits are available: Standard rate benefits, housing support, one-time payments, and supplementary benefits. The standard rate benefits are paid as monthly lump sum amounts for each member of the household. ${ }^{3}$ In 1998 the average standard rate for the household head was about DM 541. Age-adjusted, reduced rates are paid for

\footnotetext{
3 The amounts are adjusted annually by regional governments, to account for regional cost of living differences. Figure 1 presents the development of average (real) standard rates over time. For a review of the discussion on how standard rates are to be determined see Riphahn (1999).
} 
each additional household member. ${ }^{4}$ In addition to standard rate benefits, expenses for rent and heating are typically fully covered by income support. One-time payments are available for situations of special need, e.g. if the household has to move. Since certain groups of recipients incur expenditures above the average, supplementary benefits provide premia on top of the standard rates: recipients above age 65, disabled persons, and pregnant women receive another 20 percent of the standard rate, and for single parents or handicapped individuals premia of 40 or 60 percent of the standard rate are possible.

In contrast to the income support program, benefits of support in special circumstances are not standardized. The law regulates each special situation separately, therefore we do not discuss these items in detail (see Schulte and Trenk-Hinterberger 1986).

Income support eligibility follows if first, an individual's need exceeds the available net income, and second if that need cannot be met by other means, e.g. from wealth or property sale. While in principle all property needs to be sold before social assistance benefits can be claimed, a few exceptions are granted. Most importantly small homes, in which the individuals' households reside, do not necessarily have to be sold, particularly when the need appears to be temporary. An individual may not be eligible for support if the need can be met out of the disposable income or property of a spouse or unmarried partner who lives in the same household.

The eligibility requirements for support in special circumstances are not as harsh and do not

${ }^{4}$ Another 50 percent of the standard rate is paid for children under age 7, another 65 percent for children up to age 14, 90 percent for those aged 15 through 18, and 80 percent for other adults in the household. The eligibility determination accounts for the household situation of the core family or "community of need" (Bedarfsgemeinschaft). Since this "community of need" is typically identical with the household, it is approximated here using the household structure, which is available in the data. 
require the individual to first use all net income and to liquidate all property items. ${ }^{5}$ The law here specifies more generous earnings disregards, i.e. limits below which individuals and households will not be asked to utilize their incomes. The applicable type of income disregard again varies with the particular type of circumstance.

\section{Data}

\subsection{The EVS Data}

This evaluation of take-up behavior and its determinants applies the most recent available EVS data of 1993, which, to my knowledge, has not been analysed for this purpose before. There are a number of advantages to using the EVS: (i) Using the same database as past researchers permits a comparison of findings, and an evaluation of changes over time. (ii) The EVS focuses on incomes and expenditures and therefore yields potentially more precise information and suffers less item-nonresponse than comparable datasets. (iii) The EVS gathers information for a large number of households. The data used here contains the response of 40,230 households (by comparison, the German Socioeconomic Panel covers 7,000 households).

The EVS data consists of a baseline interview (Jan. 1, 1993), continuous annual data, and a conclusion interview (Dec. 31, 1993) in which property and wealth information are gathered. Participation in the EVS survey requires the households to continuously note major incomes and expenditures during the calendar year. During one month participants write down every expenditure in certain categories in great detail. Given the burden that the survey imposes on the respondents, between 60 and 70 percent of a randomly selected sample would refuse to participate (Euler 1992).

\footnotetext{
${ }^{5}$ As of 1998 individuals receiving income support could keep up to DM 2,500 in passbook savings, while those receiving e.g. support for integration of the handicapped, could keep savings of up to DM 4,500.
} 
Therefore the survey is not representative and purposely selects its sample based on the distribution of certain household characteristics taken from the Mikrozensus of the preceding year. ${ }^{6}$ In addition, high income households are excluded from the sample because they tend to be particularly reluctant to provide financial information (the cutoff in 1993 was at a monthly income of DM 35,000, about 21,000 1993 USD). Individuals in institutions and those without a permanent home, are not surveyed. In contrast to prior EVS surveys, the 1993 wave was the first to consider foreign and East German households.

As in other studies, the problem of non-representative data is addressed through the application of sample weights. The sample weights provided with the EVS data are based on the Mikrozensus of the year preceding the EVS. The 40,230 households observed in the EVS data are weighted to represent the 35.6 million actual German households as of 1993.

\subsection{Measuring Non Take-up}

To determine whether a household takes up income support, first its eligibility has to be established. As described above, eligibility requires that actual household net income falls short of the (household size adjusted) minimum income, and that the property and financial wealth of eligible households remains below a household size adjusted maximum. Therefore four figures must be calculated to determine eligibility: (i) actual household net income (ii) household specific minimum income, (iii) actual household wealth, and (iv) household specific maximum wealth.

6 The Mikrozensus is an obligatory annual representative survey of one percent of the German households. The considered household characteristics are age, labor force and marital status of the household head, household size, and household income (Euler 1992). Typically EVS households receive a bonus of DM 100 after completing the final questionnaire, an amount too small to be a participation incentive or a payment for the inconveniences. 
Most complex is the calculation of household specific minimum income (item ii). It consists of standard rate benefits, supplementary benefits, one time benefits, and the reimbursement of rent and heating expenditures. Standard rates are determined annually at the state level and adjust for regional cost of living differences. The age adjusted standard rates are then summed up for all household members (cf. footnote 4).

Based on data availability, the following supplementary benefits are considered: (i) 20 percent for those above age 65 , (ii) 40 percent for single parents with either one child under age 7 , or two or three children under age 16, (iii) 60 percent for single parents with four or more children, and (iv) supplements of an "appropriate amount" for employed individuals. ${ }^{7}$ This appears to be the first time that this employment supplement is considered in a study on hidden poverty in Germany. Finally, an overall adjustment for one time benefits at 10 percent of the standard rate as well as rent and heating expenditures are added to yield the household specific minimum income (item ii). ${ }^{8}$

This minimum income then has to be compared to actual household net income (item i), which is provided directly in the data. However, this annual income figure includes benefits received from the social assistance program. Clearly, this amount has to be deducted from household net income, before eligibility for income support benefits is determined. After the correction for the labor force supplement, consideration of this deduction is the second important aspect in which our calculation

\footnotetext{
${ }^{7}$ In June of 1993 the regulation on supplementary benefits for employed income support recipients was modified. However, inspite of complicated calculation procedures this change made no differnce for any given individual, leaving our calculations unaffected (for details see Bäcker and Hanesch 1998).

${ }^{8}$ For renters the expenditure categories "rent" and "energy" were considered. For home owners, the EVS presents a "rental value of owned appartment" which was used as a conservative approximation of rent expenditures in these households. Clearly, the imputation of the rental value introduces measurement error into the calculation. If it overestimates the dwelling expenditures relative to the calculation procedures of the social assistance administration, the number of poor households will be overestimated for the group of home owners, and vice versa.
} 
procedure improves on the existing literature.

A third improvement consists of controls for the second step in the eligibility determination, i.e. the comparison of household financial wealth (item iii) to the maximum permitted wealth under entitlement conditions (item iv), which was ignored in prior studies. These conditions demand that (as of 1993) a household may possess the sum of DM 2,500 for the head, 1,200 for a partner or spouse, and DM 500 for each child (item iv). The EVS conclusion interview investigates in detail the financial and property wealth of each household, based on which actual household wealth is calculated. ${ }^{9}$ Those households for which actual wealth exceeds the maximum permissible level (item iv), are not eligible for income support benefits.

One remaining imperfection in the calculation is that it does not account for the restrictive effects of property ownership on income support eligibility. However, the regulations on permissible home ownership are not sufficiently clear to impute their effect on individual households. ${ }^{10}$ If we assume that property and financial wealth of households are highly correlated, then controlling for financial wealth will already correct for much of the measurement error. Section 5.3 presents sensitivity tests on the improvements in our calculation approach.

\subsection{Descriptive Statistics}

Table 2 describes items (i) through (iv) used in the determination of income support eligibility. Poor, i.e. benefit eligible households clearly have lower incomes and financial wealth than the full

9 The considered items describe: Total sum of building society savings agreements, bonds, shares in mutual funds and stocks, savings accounts, other financial assets, and sum of checking account balances, which may be negative.

${ }^{10}$ While some home ownership is acceptable for income support recipients, other property holdings will be deemed too valuable. The determination of this issue is legally complex and is determined by factors such as household composition, value and size of the property, as well as the alternative local cost of renting appartments. 
sample. Interestingly, the hidden poor households, i.e. those who do not take up their benefits, appear to be slightly better off in terms of household net income than those who take up state transfers. The low minimum income and permissible wealth among poor households relate to their relatively small household size.

Poor households are more frequent among single person and single parent households than in the overall sample. Their heads are typically female, slightly younger, and less educated than the sample average. Poor households are more likely to reside in large towns, more likely to be in West Germany and much more likely to be of non German nationality.

Three measures are applied to describe the extent and degree of hidden poverty: (i) The share of the hidden poor among the poor and among all households, (ii) the amount of income that hidden poor households fall short of the minimum (poverty gap), and (iii) the share of this gap in minimum income (degree of poverty). Table 3 provides these indicators.

Prior to income support payments 3.25 percent of all households have incomes and wealth below the poverty limits as defined by the income support program. This rate shrinks to 2.04 percent once we take out those households who indicate receipt of income support. This implies a non take-up rate of 62.7 percent, a rate above the figures obtained for past years (cf. Table 1). Hartmann found non take-up of 48 percent for 1979, Hauser and Semrau (1990) even mentioned non take-up of about 30 percent for 1983, and Neumann and Hertz (1998) concluded that non take-up reached 59 and 53 percent of the poor households in 1991 and 1995.

To describe the effects of our calculation procedure on the results, Table 3 reports on sensitivity tests: Taking the employment related supplemental benefit into account increased the measure of overall and hidden poverty. When this factor is omitted, hidden poverty would amount to 
58 percent instead of 62.7 percent of all poor households. We find a large effect of the "no wealth condition." Without screening out households which are ineligible because they own too much wealth, we would have obtained an overall poverty rate of over 7 vs. 3.25 percent now. ${ }^{11}$ Omitting one time benefits from the minimum income calculation reduces the share of poor households, because the calculated minimum income declines and more households pass the lowered limit. Scenario four shows the expected increase in poverty rates following the correction for income support benefits in the calculation of actual incomes. The simulation presented in the last row of Table 3 shows that had we applied the procedures common to prior studies in this literature, the rate would have been even higher, at 84 percent and households who are not taking up their benefits would have accounted for over four percent of all households. This shows that the improvements in calculation procedures have sizeable effects.

Whereas the poverty and take-up rates vary largely across scenarios, the average poverty gap and degree of poverty are remarkably stable. Hidden poor households on average forgo about DM 240 per month, i.e. about 13 percent (one seventh) of the average minimum income.

Table 4 describes the frequency of hidden poverty across household types. The first four rows depict the probability of hidden poverty by households' rank in the distribution of unmet needs, i.e. the absolute poverty gap and the relative poverty degree. Clearly, take-up increases with expected benefits and is lowest among households with small claims. This confirms the hypotheses derived in the models of Anderson and Meyer (1997), or Blundell et al. (1988).

East German households appear to be more likely to remain in hidden poverty than their West German counterparts, and foreign households seem to be more likely to take up benefits. The

11 Kortmann (1978, p.132) cites a finding of Klanberg that about 20 percent of poor households have wealth beyond the maximum disregard. In our data that share is much higher. 
univariate frequencies confirm urban/ rural differences in take-up rates (Hartmann 1985). The effects of human capital on take-up are inconclusive: Take-up is high among those with low degrees of schooling and with high vocational degrees. Based on the age effects, the take-up rate seems to decline over the life cycle of the household head. Single parent households have very low and households without children have high rates of non take-up. The joint effects of these factors are analysed next.

\section{Empirical Tests of Hypotheses}

\subsection{The Specification}

This section extends the analysis of non take-up to a multivariate framework, to test the hypotheses derived in the theoretical models described above. The reason for not claiming benefits is generally modelled in form of an implied cost, such that benefit take-up is more likely if benefits are high, if the duration of benefit receipt is long, and if take-up costs are low (Anderson and Meyer 1997). Based on these arguments we test the effects of benefit amount, and of variables which approximate benefit duration, application cost, and stigma.

To evaluate the effects of benefit entitlement the poverty gap and poverty degree measures are applied. A number of variables can be used to approximate benefit duration: If e.g. the head of a household is retired and retirement benefits are insufficient, the need for public support will be permanent. Therefore we control for whether the household head reached retirement age (age 65) and expect a positive effect on the take-up probability. Information on handicap status would also be a suitable proxy variable, but unfortunately the data does not provide this indicator. Further, we use the presence of young children under age seven in single parent households as a duration indicator. These 
households are likely to depend on outside support for another few years, during which employment opportunities of the single parent are limited due to child care obligation. Finally, we use variables describing the earnings potential of a household to approximate the duration for which the household will need income support. If the head of a household is well educated, it is hypothesized that benefit receipt may be short term and therefore take-up can be expected to be lower. The same reasoning applies when we compare households who own and rent an appartment: If owner households have on average higher earnings potentials they may need assistance for shorter periods and will be less likely to take up benefits. ${ }^{12}$

To operationalize application cost we consider whether a household is of German or foreign nationality, assuming that it is more difficult for a foreign household to obtain the necessary information. This suggests that foreign households are less likely to take up benefits.

The amount of stigma a household feels is approximated by four measures. First, the age and sex of the household head is included: Social norms may render a situation in which an individual is not able to provide for one's household a more stigmatizing event for men than for women. This may also vary across birth cohorts. Second, living in a small community will make it harder to shield the information on income support dependence from the public. Therefore we expect households in towns with less than 20,000 inhabitants to be less likely to take up benefits. The opposite effect holds for bigger cities, where anonymity may protect the applicant from stigmatization and take-up could be higher. Third, we know that social assistance in former East Germany, where individuals not only had the right but also the obligation to work, had a negative connotation (Neumann and Hertz 1998).

\footnotetext{
${ }^{12}$ Additionally, footnote 8 pointed out the potential for measurement error in the imputed value of home ownership. By considering the indicator for home ownership in the specification, the potentially biasing effect of the measurement problem can be controlled for.
} 
Therefore stigma effects may be higher in East than in West Germany, yielding potentially lower takeup there. Finally, the presence of children may be a motivation for parents to ensure that the means of subsistence are provided. While adults might save and make do with fewer resources if it concerned only themselves, take-up is hypothesized to respond positively to the presence of children.

Descriptive statistics on the explanatory variables used in the regression analysis are provided in the second column of Table 5. The relevant sample is the group of households who are poor prior to income support transfers. The dependent variable is coded one for households who do not take up income support, and zero for beneficiaries of the social assistance program.

\subsection{Estimation Results}

A probit estimator is applied to the dichotomous dependent variable. Estimation results on three alternative specifications are presented in the columns (1) through (3) of Table 5. The three specifications differ in that the first controls for the absolute amount of monthly benefits (the poverty gap), the second controls for the relative degree of poverty, and the final specification reestimates the second adding controls for state fixed effects. Such fixed effects are controlled for, since states regulate some administrative issues connected to the social assistance programs, most importantly the standard rates. Insofar as different standard rates and state level regulations induce different behaviors, these effects are controlled for by state fixed effects. Additionally, the fixed effects control for the takeup effects of overall macroeconomic and labor market conditions, which vary vastly by state.

The estimation results broadly confirm our hypotheses: Higher benefit claims significantly reduce the probability of non take-up, confirming the findings of the international literature (cf. Anderson and Meyer 1997, or Blundell et al. 1988). Since for inter-household comparison a relative 
benefit measure (e.g. the poverty degree) appears more appropriate than the absolute benefit amount (i.e. the poverty gap), and because specification (2) yields a higher log likelihood value, the poverty degree is preferred for the final specification in column (3). ${ }^{13}$ Simulation experiments (not presented) yield that a ten percent increase in either benefit measure yields a response in the probability of non take-up of about two percentage points or three percent, which is the same magnitude Anderson and Meyer (1997) found in their study. However, relative to the marginal effects of other household characteristics (discussed below, see Table 5) this effect is indeed modest.

With the exception of the insignificant "head of retirement age" effect, all measures approximating the duration effect on benefit take-up confirm our hypotheses, several at high levels of statistical significance. With respect to having a household head of retirement age we need to keep in mind that the specification also controls for the age of the head as a stigma variable. There it has the expected negative sign, indicating that older heads are correlated with lower rates of non take-up, the hypothesized duration effect. ${ }^{14}$

As expected, single parents with young children have significantly lower rates of non take-up. The marginal effects in Table 5 indicate that being a single parent with children reduces the already low non take-up rate in households with children by another 17 percent. ${ }^{15}$ Having a household head with

13 An estimation which controlled for both, the absolute amount and the relative size of the potential benefit, resulted in an insignificant coefficient estimate for the latter and a highly significant estimate with a nearly unchanged coefficient for the poverty degree.

${ }^{14}$ In test runs, which did not control for age, the "head of retirement age" variable had a negative effect on non take-up, confirming the duration hypotheses, even though it was statistically insignificant.

15 The sizeable interaction effect obtains even if additional separate indicators for single parent households and for households with children under age 7 are considered. In this scenario however it loses its statistical significance, possibly because the effect of children is overspecified in such a model. Also more than 92 percent of the single parent households are female headed and this effect is also already captured in a different variable. 
little or average schooling reduces the rate of non take-up. The suggested interpretation is that relative to households with highly educated heads these households cannot expect to improve their economic situation fast, as their human capital is low. Since therefore the expected duration of transfer receipt is longer, the probability of non take-up declines. ${ }^{16}$

Finally, home ownership, interpreted as the outcome of a superior earnings profile, is significantly correlated with a much higher rate of benefit non take-up. The interpretation may either follow that of human capital variables, or one may consider the significant home ownership effect as an indicator of overestimated imputed rental values of owned homes. Among the dichotomous indicators, home ownership has the largest marginal effect, increasing the probability of non take-up by 35.6 percent (see Table 5).

The proxy variable chosen to reflect application costs is foreign nationality. It has the expected positive effect on non take-up. Though it is imprecisely estimate, this suggests that foreign households are less likely to take up the benefit they are entitled to. This is a reversal of the effect in the univariate statistics in Table 4 and shows that once other characteristics are controlled for, non take-up is more frequent among foreign than among observationally equivalent German households, also confirming the result of Neumann and Hertz (1998).

Whereas we expected a significant difference in take-up behavior between male and female household heads, this hypothesis is not borne out by the data. The community size effects confirm that individuals living in large cities tend to have (insignificantly) higher take-up rates, and those residing in small towns are significantly less likely to take up their benefits. East German households do not differ

\footnotetext{
${ }^{16}$ In prior estimations we additionally controlled for the effect of vocational training. However, even when no further human capital indicators were considered, these variables did not significantly improve the explanatory power of the model. Therefore they are excluded in the final specification.
} 
significantly from their western counterparts in their response to the presence of the transfer program. The hypothesis on the significant impact of the presence of children on household take-up behavior is impressively confirmed.

\section{Summary and Conclusion}

This paper investigates the phenomenon of non take-up of public transfers: its theoretical explanation, its extent at the example of German social assistance program, and its empirical determinants. German studies identified a downward trend in non take-up from 61 percent of all eligible households in 1963, to 48 percent in 1979, and down to 30 percent in 1990. Recently, Neumann and Hertz (1998) found evidence for an increase in non take-up rates, back to 59 and 52 percent for the years 1991 and 1995. They applied data from the German Socioeconomic Panel, which had not been used for this type of analysis before. Their conclusions are confirmed here based on information from a large 1993 dataset with more than 40,000 households: About 63 percent of all poor households did not take up the income support benefits available to them. This amounts to about 2 percent of all German households, about 700,000 households with approximately 1.3 million individuals. If every household were to take up available benefits, actual expenditures on income support for noninstitutionalized households in 1993 would have increased by 16.8 percent. ${ }^{17}$ Since take-up rates have fallen in recent years, the secular increase in income support dependence cannot be due to a decline in take-up rates.

17700,000 households with an average claim of DM 272 per month generate an additional annual expenditure of DM 2.28 billion, which is compared to actual gross expenditures of DM 13.6 billion on general income support for noninstitutionalized households in 1993 (cf. Neuhäuser 1995). Relating it to the gross income support expenditures for all households, yields an increase by 12.7 percent, whereas relative to the entire social assistance program's gross expenditures, i.e. including support in special circumstances, expenditures would have increased by only 4.7 percent. 
The model first presented by Anderson and Meyer (1997) shows that the cost of applying for income support benefits, the amount and duration of the expected benefits, as well as factors affecting individually perceived stigma are likely determinants of benefit non take-up. An empirical test of these hypotheses yielded generally confirming evidence: A rise in expected benefits by 20 percent would increase the rate of benefit take-up by about six percent. Expectation of a long benefit duration increases the tendency to take up the available provisions. Foreign households, whose application cost likely exceed those of natives, have (insignificantly) lower rates of take-up, and individuals, who by living in a small community might be subject to stigmatization, are also less likely to claim the transfers.

While these estimates test the microeconomic conditions for income support take-up, they cannot explain the shifts in take-up rates over time. The sensitivity analyses presented above show that the findings on hidden poverty vary depending on the applied calculation procedures. In fact, not correcting for prior methodological shortcomings would have yielded a rate of hidden poor households in the population twice that found here. It would therefore be a worthwhile future research endeavour, to calculate non take-up by homogenous procedures for all available EVS datasets over the last three decades. Once reliable estimates of the trend in take-up rates are available, its determinants can be evaluated. 


\section{References}

Adam, H., 1977, Zur Armutsdiskussion in der Bundesrepublik Deutschland, Sozialer Fortschritt 26(2), 37-39.

Anderson, Patricia M. and Bruce D. Meyer, 1997, Unemployment Insurance Takeup Rates and the After-Tax Value of Benefits, Quarterly Journal of Economics 112(3), 913-937.

Ashenfelter, Orley, 1983, Determining Participation in Income-Tested Social Programs, Journal of the American Statistical Association 78(383), 517-525.

Atkinson, Anthony Barnes, 1989, The Take-Up of Social Security Benefits, in: Atkinson, A.B. (ed.), Poverty and Social Security, Harvester Wheatsheaf, New York, London, 190-207.

Blank, Rebecca M. and David E. Card, 1991, Recent Trends in Insured and Uninsured Unemployment: Is There an Explanation?, Quarterly Journal of Economics 106(4), 11571189.

Blank, Rebecca M. and Patricia Ruggles, 1996, When Do Women use Aid to Families with Dependent Children and Food Stamps? The Dynamics of Eligibility versus Participation, Journal of Human Resources 31(1), 57-89.

Blundell, Richard, Vanessa Fry, and Ian Walker, 1988, Modelling the Take-Up of Means-Tested Benefits: The Case of Housing Benefits in the United Kingdom, Economic Journal 98(390, Supplement), 58-74.

Craig, Peter, 1991, Costs and Benefits: A Review of Research on Take-Up of Income Related Benefits, Journal of Social Policy 20(4), 537-565.

Duclos, Jean-Yves, 1995, Modelling the Take-up of State Support, Journal of Public Economics 58(3), 391-415.

Euler, Manfred, 1992, Einkommens- und Verbrauchsstichprobe 1993, Wirtschaft und Statistik 7/92, 463-469.

Fry, Vanessa, and Graham Stark, 1989, The Take-Up of Supplementary Benefit: Gaps in the 'Safety Net'?, in: Andrew Dilnot and Ian Walker, The Economics of Social Security, Oxford University Press, 179-191.

Hartmann, Helmut, 1985, Armut trotz Sozialhilfe. Zur Nichtinanspruchnahme von Sozialhilfe in der Bundesrepublik, in: Leibfried, Stephan and Florian Tennstedt (eds.), Politik der Armut und Spaltung des Sozialstaats, Suhrkamp Verlag, Frankfurt a.M., 169-189.

Hauser, Richard, Helga Cremer-Schäfer, Udo Nouvertné, 1981, Armut, Niedrigeinkommen und Unterversorgung in der Bundesrepublik Deutschland. Bestandsaufnahme und sozialpolitische Perspektiven, Campus Verlag, Frankfurt / New York.

Hauser, Richard and Peter Semrau, 1990, Zur Entwicklung der Einkommensarmut von 1963 bis 1986, Sozialer Fortschritt 39(1), 27-36.

Kim, Marlene and Thanos Mergoupis, 1997, The Working Poor and Welfare Recipiency: Participation, Evidence, and Policy Directions, Journal of Economic Issues 31(3), 707-728. 
Klanberg, Frank, 1979, Einkommensarmut 1969 und 1973 bei Anlegung verschiedener Standards, Sozialer Fortschritt 28(6), 127-131.

Kortmann, Klaus, 1978, Probleme der Armut im Sozialstaat, in: Pfaff, Martin and Hubert Voigtländer (eds.), Sozialpolitik im Wandel. Von der selektiven zur integrierten Sozialpolitik, Verlag Neue Gesellschaft GmbH, Bonn, 127-144.

McCall, Brian, 1995, The Impact of Unemployment Insurance Benefit Levels on Recipiency, Journal of Business and Economic Statistics 13(2), 189-198.

Moffitt, Robert, 1983, An Economic Model of Welfare Stigma, American Economic Review 73(5), 1023-1035.

Neuhäuser, Jenny, 1995, Sozialhilfeaufwand 1993, Wirtschaft und Statistik 95(2), 147-154.

Neumann, Udo and Markus Hertz, 1998, Verdeckte Armut in Deutschland, ISL Institut für Sozialberichterstattung \& Lebenslagenforschung, Forschungsbericht im Auftrag der FriedrichEbert-Stiftung.

OECD, 1998a, The Battle against Exclusion. Social Assistance in Australia, Finland, Sweden and the United Kingdom, Paris.

OECD, 1998b, The Battle against Exclusion. Social Assistance in Belgium, the Czech Republic, the Netherlands and Norway, (Volume 2) Paris.

Riphahn, Regina T., 1999, Why Did Social Assistance Dependence Increase? - The Dynamics of Social Assistance Dependence and Unemployment in Germany, 1999, unpublished Habilitationsschrift, University of Munich.

Schulte, Bernd and Peter Trenk-Hinterberger, 1986, Sozialhilfe. Eine Einführung, C.F. Müller Juristischer Verlag, Heidelberg, second edition.

Schulz, Joachim, 1989, Das Problem der ,Dunkelziffer der Armut', in: Schulz, Joachim, Armut und Sozialhilfe, Verlag Kohlhammer, Stuttgart, 190-201.

STBA (Statistisches Bundesamt), 1999, Pressemitteilung 29.7., Pressemitteilung 31.8.1999, http://www.statistik-bund.de.

Transfer-Enquête-Kommission, 1981, Das Transfersystem in der Bundesrepublik Deutschland, Bericht der Sachverständigenkommission zur Ermittlung des Einflusses staatlicher Transfereinkommen auf das verfügbare Einkommen der privaten Haushalte, Verlag W. Kohlhammer, Stuttgart.

van Oorschot, Wim J.H., 1991, Non-Take-Up of Social Security Benefits in Europe, Journal of European Social Policy 1(1), 15-30.

van Oorschot, Wim J.H., 1994, Take it or Leave it. A Study of Non-Take-Up of Social Security Benefits, Tisser Series on Work and Social Security, Tilburg University Press.

Yaniv, Gideon, 1997, Welfare Fraud and Welfare Stigma, Journal of Economic Psychology 18(4), 435-451. 
Table 1: German Studies on Social Assistance Take-up

\begin{tabular}{|c|c|c|c|c|c|c|c|}
\hline Author & $\begin{array}{l}\text { Publication } \\
\text { Year }\end{array}$ & Data Source & $\begin{array}{l}\text { Data } \\
\text { Year }\end{array}$ & $\begin{array}{l}\text { Number of } \\
\text { Poor } \\
\text { Households }{ }^{1)}\end{array}$ & $\begin{array}{l}\text { Share in All } \\
\text { Households }\end{array}$ & $\begin{array}{l}\text { Number of } \\
\text { Hidden Poor } \\
\text { Households }{ }^{1)}\end{array}$ & $\begin{array}{l}\text { Share of } \\
\text { Hidden in All } \\
\text { Poor } \\
\text { Households }\end{array}$ \\
\hline (1) Kortmann & 1978 & IMDAF (based on EVS) & 1969 & n.a. & $0.7 \%$ & n.a & n.a. \\
\hline (2) Klanberg & 1979 & $\begin{array}{l}\text { EVS (Income and Expenditure } \\
\text { Survey) }\end{array}$ & $\begin{array}{l}1969 \\
1973\end{array}$ & $\begin{array}{l}\text { 69a: } 237,000 \\
\text { 73a: } 343,000 \\
\text { 73b: } 100,000^{2)}\end{array}$ & $\begin{array}{l}\text { 69a: } 1.1 \% \\
\text { 73a: } 1.6 \% \\
\text { 73b: } 0.5 \%\end{array}$ & n.a. & n.a. \\
\hline $\begin{array}{l}\text { (3) Transfer-Enquête- } \\
\text { Kommission }\end{array}$ & 1981 & $\begin{array}{l}\text { EVS (Income and Expenditure } \\
\text { Survey) }\end{array}$ & 1973 & 350 & $1.6 \%$ & 116.667 & $33 \%$ \\
\hline (4) Hauser et al. & 1981 & $\begin{array}{l}\text { EVS (Income and Expenditure } \\
\text { Survey) }\end{array}$ & $\begin{array}{l}1963, \\
1969, \\
1973\end{array}$ & $\begin{array}{l}\text { 63: } 1,160,000 \\
\text { 69: } 778,000 \\
73: 962,000\end{array}$ & $\begin{array}{l}\text { 63: } 5.8 \% \\
\text { 69: } 3.6 \% \\
73: 4.4 \%\end{array}$ & $\begin{array}{l}\text { 63: } 709,000 \\
\text { 69: } 352,000 \\
73: 457,000\end{array}$ & $\begin{array}{l}\text { 63: } 61 \% \\
\text { 69: } 45 \% \\
\text { 73: } 48 \%\end{array}$ \\
\hline (5) Hartmann & 1985 & Survey of 25,000 Households & 1979 & $1,144,000$ & $5.0 \%$ & 550000 & $48 \%$ \\
\hline (6) Hauser and Semrau & 1990 & $\begin{array}{l}\text { EVS (Income and Expenditure } \\
\text { Survey) }\end{array}$ & 1983 & n.a. & n.a. & n.a. & $30 \%$ \\
\hline (7) Neumann and Hertz & 1998 & German Socioeconomic Panel & $\begin{array}{l}1991, \\
1995\end{array}$ & n.a. ${ }^{3)}$ & n.a. ${ }^{3)}$ & n.a. ${ }^{3)}$ & $\begin{array}{l}91: 58.7 \% \\
95: 52.3 \%\end{array}$ \\
\hline
\end{tabular}

Note: 1) Households are considered poor if their income falls below that minimum determined by the income support program. They are in hidden poverty, if they do not claim income support benefits available to them.

2) Klanberg distinguishes a net income concept from a 'full income' concept. Figures based on the former are labelled a, the latter $b$.

3) The calculations by Neumann and Hertz are in terms of individuals as opposed to households. 
Table 2: Descriptive Statistics

\begin{tabular}{|c|c|c|c|}
\hline Variable Description & Full Sample & $\begin{array}{c}\text { All Poor } \\
\text { Households }\end{array}$ & $\begin{array}{l}\text { Hidden Poor } \\
\text { Households } \\
\end{array}$ \\
\hline \multicolumn{4}{|l|}{ Household Characteristics } \\
\hline $\begin{array}{l}\text { i) Household net income } \\
\text { (in DM per year) }\end{array}$ & $\begin{array}{c}52,316 \\
(35,775)\end{array}$ & $\begin{array}{l}15,878 \\
(9,352)\end{array}$ & $\begin{array}{l}17,750 \\
(9,433)\end{array}$ \\
\hline $\begin{array}{l}\text { ii) Minimum Income } \\
\text { (in DM per year) }\end{array}$ & $\begin{array}{c}26,482 \\
(12,701)\end{array}$ & $\begin{array}{c}21,207 \\
(10,291)\end{array}$ & $\begin{array}{c}20,647 \\
(10,823)\end{array}$ \\
\hline $\begin{array}{l}\text { iii) Actual wealth } \\
\text { (in DM) }\end{array}$ & $\begin{array}{c}40,609 \\
(76,227)\end{array}$ & $\begin{array}{c}-271 \\
(8,309)\end{array}$ & $\begin{array}{c}-554 \\
(10,287)\end{array}$ \\
\hline iv) Permissible wealth (in DM) & $\begin{array}{l}3,545 \\
(880)\end{array}$ & $\begin{array}{l}3,166 \\
(865)\end{array}$ & $\begin{array}{l}3,082 \\
(856)\end{array}$ \\
\hline Household size & $\begin{array}{c}2.27 \\
(1.24)\end{array}$ & $\begin{array}{c}2.01 \\
(1.37)\end{array}$ & $\begin{array}{c}1.80 \\
(1.27)\end{array}$ \\
\hline Single person household & $\begin{array}{l}.33 \\
(.47)\end{array}$ & $\begin{array}{l}.51 \\
(.50)\end{array}$ & $\begin{array}{l}.60 \\
(.49)\end{array}$ \\
\hline Single parent household & $\begin{array}{l}.05 \\
(.22)\end{array}$ & $\begin{array}{l}.22 \\
(.41)\end{array}$ & $\begin{array}{l}.13 \\
(.33)\end{array}$ \\
\hline Number of children under 16 & $\begin{array}{l}.45 \\
(.85)\end{array}$ & $\begin{array}{c}.60 \\
(1.03)\end{array}$ & $\begin{array}{l}.43 \\
(.95)\end{array}$ \\
\hline Number of children under 7 & $\begin{array}{l}.21 \\
(.54)\end{array}$ & $\begin{array}{l}.27 \\
(.61)\end{array}$ & $\begin{array}{l}.18 \\
(.51)\end{array}$ \\
\hline \multicolumn{4}{|l|}{ Characteristics of Household Head } \\
\hline Female & $\begin{array}{l}.35 \\
(.48)\end{array}$ & $\begin{array}{l}.60 \\
(.49)\end{array}$ & $\begin{array}{l}.58 \\
(.49)\end{array}$ \\
\hline Age & $\begin{array}{c}50.8 \\
(16.6)\end{array}$ & $\begin{array}{c}48.1 \\
(18.5)\end{array}$ & $\begin{array}{c}49.6 \\
(19.4)\end{array}$ \\
\hline Schooling: None or basic & $\begin{array}{l}.43 \\
(.49)\end{array}$ & $\begin{array}{l}.56 \\
(.49)\end{array}$ & $\begin{array}{l}.54 \\
(.50)\end{array}$ \\
\hline Schooling: Medium (Realschule) & $\begin{array}{l}.27 \\
(.44)\end{array}$ & $\begin{array}{l}.23 \\
(.42)\end{array}$ & $\begin{array}{l}.23 \\
(.42)\end{array}$ \\
\hline Schooling: 12 / 13 years & $\begin{array}{l}.30 \\
(.46)\end{array}$ & $\begin{array}{l}.21 \\
(.41)\end{array}$ & $\begin{array}{c}.23 \\
(.42)\end{array}$ \\
\hline Vocational Training: None & $\begin{array}{c}.12 \\
(.33)\end{array}$ & $\begin{array}{c}.33 \\
(.47)\end{array}$ & $\begin{array}{c}.35 \\
(.48)\end{array}$ \\
\hline Vocational Training: Apprenticeship & $\begin{array}{c}.68 \\
(.46)\end{array}$ & $\begin{array}{c}.60 \\
(.49)\end{array}$ & $\begin{array}{c}.60 \\
(.49)\end{array}$ \\
\hline Vocational Training: Univ. degree & $\begin{array}{c}.19 \\
(.40)\end{array}$ & $\begin{array}{c}.07 \\
(.25)\end{array}$ & $\begin{array}{c}.06 \\
(.23)\end{array}$ \\
\hline \multicolumn{4}{|l|}{ Nationality and Residence } \\
\hline Town $<20,000$ inhabitants & $\begin{array}{c}.35 \\
(.48)\end{array}$ & $\begin{array}{c}.33 \\
(.47)\end{array}$ & $\begin{array}{c}.37 \\
(.48)\end{array}$ \\
\hline City $>100,000$ inhabitants & $\begin{array}{c}.35 \\
(.48)\end{array}$ & $\begin{array}{c}.42 \\
(.49)\end{array}$ & $\begin{array}{c}.38 \\
(.48)\end{array}$ \\
\hline East German & $\begin{array}{c}.23 \\
(.42)\end{array}$ & $\begin{array}{c}.14 \\
(.34)\end{array}$ & $\begin{array}{c}.17 \\
(.38)\end{array}$ \\
\hline Foreign nationality & $\begin{array}{c}.02 \\
(.13)\end{array}$ & $\begin{array}{c}.04 \\
(.20)\end{array}$ & $\begin{array}{c}.03 \\
(.18)\end{array}$ \\
\hline
\end{tabular}


Note: 1) Presented are the variable means with standard deviations in parentheses.

2) All statistics are weighted by EVS sample weights for the full sample.

3) Poor households are defined by a positive difference between the minimum household income calculated by social assistance rules and the actual net income available to the household (net of social assistance benefits), who also do not possess more than the maximum permissible wealth. Hidden poor households are those poor households who are not taking up their social assistance benefits.

Table 3: Sensitivity of the Hidden Poverty Measure to Various Assumptions

\begin{tabular}{lccccc}
\hline Scenario & $\begin{array}{c}\text { Poverty } \\
\text { Rate } \\
\text { (in } \\
\text { percent) }\end{array}$ & $\begin{array}{c}\text { Hidden Poverty } \\
\text { in percent } \\
\text { of Poor Hh. of All } \\
\text { Hh. }\end{array}$ & $\begin{array}{c}\text { Poverty Gap } \\
\text { (in DM per } \\
\text { month) }\end{array}$ & $\begin{array}{c}\text { Degree of } \\
\text { Poverty } \\
\text { (in perct.) }\end{array}$ \\
\hline Base Case & 3.25 & 62.7 & 2.04 & 241.5 & 13.6 \\
$\begin{array}{l}\text { Specification Tests: } \\
\text { 1) No correction for labor }\end{array}$ & 2.75 & 58.0 & 1.59 & 236.9 & 13.1 \\
force participation & & & & & \\
2) No wealth condition & 7.12 & 77.0 & 5.48 & 296.9 & 14.1 \\
3) No one-time benefits & 2.89 & 59.2 & 1.71 & 232.7 & 12.9 \\
$\begin{array}{l}\text { 4) No correction for social } \\
\text { assistance income }\end{array}$ & 2.77 & 73.7 & 2.04 & 241.5 & 13.6 \\
5) $1+2+4$ & & & & & \\
\hline
\end{tabular}

Note: 1) Poverty Rate describes the share of poor households in the total population in percent. Hidden Poverty describes the share of hidden poor households among poor households and in the total population (i.e. non take-up) in percent. Poverty Gap describes the difference between minimum and actual income for households in hidden poverty in DM, and the Degree of Poverty calculates the ratio of poverty gap to minimum income, in percent, again only for households in hidden poverty.

2) Scenario 5 applies restrictions 1, 2, and 4 jointly, to generate a measure along the procedures applied in past reseach on hidden poverty, which generally did correct for one time benefits.

3) All statistics based on weighted data. 
Table 4: Non Take-up Rates Among Poor Households by Characteristics

\begin{tabular}{|c|c|c|c|}
\hline Characteristic & $\begin{array}{c}\text { Rate of Non } \\
\text { Take-up }\end{array}$ & Characteristic & $\begin{array}{l}\text { Rate of Non } \\
\text { Take-up }\end{array}$ \\
\hline All poor households & 62.65 & & \\
\hline First quartile of poverty gap & 89.91 & First quartile: Poverty degree & 88.45 \\
\hline Second quartile of poverty gap & 79.51 & Second quartile: Poverty degree & 80.80 \\
\hline Third quartile of poverty gap & 60.02 & Third quartile: Poverty degree & 65.61 \\
\hline Fourth quartile of poverty gap & 21.17 & Fourth quartile: Poverty degree & 15.71 \\
\hline West German households & 60.23 & Household head < age 30 & 68.27 \\
\hline East German households & 77.96 & Household head < age 40 & 53.27 \\
\hline German households & 63.16 & Household head < age 50 & 54.10 \\
\hline Foreign households & 50.87 & Household head < age 60 & 63.57 \\
\hline Towns $<20,000$ inhabitants & 70.17 & Household head < age 70 & 68.11 \\
\hline Cities $>100,000$ inhabitants & 56.22 & Household head > age 69 & 72.92 \\
\hline Household owns home & 87.69 & Single person household & 73.80 \\
\hline Household rents home & 57.66 & Single parent household & 36.42 \\
\hline Head schooling: none / basic & 60.76 & Married couple, no children & 73.86 \\
\hline Head schooling: Medium & 63.80 & Married couple, with children & 55.70 \\
\hline Head schooling: 12 / 13 years & 66.31 & Cohabiting couple, no children & 81.92 \\
\hline Head voc. traing.: None & 65.91 & Cohabiting couple, with children & 47.84 \\
\hline Head voc. traing.: Apprenticeship & 61.86 & No child under 16 & 72.11 \\
\hline Head voc. traing.: Univ. Degree & 53.60 & One child under 16 & 40.96 \\
\hline Household head female & 60.92 & Two children under 16 & 44.35 \\
\hline \multirow[t]{2}{*}{ Household head male } & 65.21 & Three children under 16 & 39.72 \\
\hline & & Four children under 16 & 45.69 \\
\hline
\end{tabular}

Note: 1) All statistics based on weighted data. 
Table 5: Estimation Results: Probit Estimation of Hidden Poverty Determinants

\begin{tabular}{|c|c|c|c|c|c|}
\hline & $\begin{array}{c}\text { Mean } \\
\text { (Std.Dev.) }\end{array}$ & (1) & (2) & (3) & $\begin{array}{l}\text { Marg. } \\
\text { Effects }\end{array}$ \\
\hline Hidden poverty (dependent variable, $0 / 1$ ) & $\begin{array}{l}.604 \\
(.489)\end{array}$ & - & - & - & - \\
\hline \multicolumn{6}{|l|}{ Benefit Effect } \\
\hline Poverty gap & $\begin{array}{c}464.3 \\
(489.6)\end{array}$ & $\begin{array}{l}-.0018 * * \\
(.0002)\end{array}$ & - & - & - \\
\hline Poverty degree & $\begin{array}{c}.249 \\
(.245)\end{array}$ & - & $\begin{array}{l}-4.143 * * \\
(.337)\end{array}$ & $\begin{array}{l}-4.174 * * \\
(.342)\end{array}$ & -1.61 \\
\hline \multicolumn{6}{|l|}{ Duration Effect } \\
\hline Head retirement age $(0 / 1)$ & $\begin{array}{l}.178 \\
(.383)\end{array}$ & $\begin{array}{l}.101 \\
(.239)\end{array}$ & $\begin{array}{l}.160 \\
(.246)\end{array}$ & $\begin{array}{l}.131 \\
(.250)\end{array}$ & .050 \\
\hline Single parent\&child under age $7(0 / 1)$ & $\begin{array}{l}.123 \\
(.329)\end{array}$ & $\begin{array}{l}-.476 * \\
(.214)\end{array}$ & $\begin{array}{l}-.356 \\
(.218)\end{array}$ & $\begin{array}{l}-.419 \text { " } \\
(.221)\end{array}$ & -.165 \\
\hline Head: Schooling basic or none $(0 / 1)$ & $\begin{array}{l}.519 \\
(.500)\end{array}$ & $\begin{array}{l}-.426 * * \\
(.156)\end{array}$ & $\begin{array}{l}-.554 * * \\
(.172)\end{array}$ & $\begin{array}{l}-.553 * * \\
(.174)\end{array}$ & -.210 \\
\hline Head: Schooling medium $(0 / 1)$ & $\begin{array}{c}.231 \\
(.422)\end{array}$ & $\begin{array}{l}-.248 \\
(.175)\end{array}$ & $\begin{array}{l}-.344 " ~ \\
(.188)\end{array}$ & $\begin{array}{l}-.322 " \\
(.187)\end{array}$ & -.126 \\
\hline Own home $(0 / 1)$ & $\begin{array}{l}.180 \\
(.384)\end{array}$ & $\begin{array}{l}1.613 * * \\
(.254)\end{array}$ & $\begin{array}{l}1.102 * * \\
(.196)\end{array}$ & $\begin{array}{l}1.120 * * \\
(.194)\end{array}$ & .356 \\
\hline \multicolumn{6}{|l|}{ Application Cost and Stigma Effect } \\
\hline Foreign Household $(0 / 1)$ & $\begin{array}{l}.049 \\
(.215)\end{array}$ & $\begin{array}{l}.232 \\
(.248)\end{array}$ & $\begin{array}{c}.283 \\
(.255)\end{array}$ & $\begin{array}{l}.220 \\
(.268)\end{array}$ & .082 \\
\hline Head: Female $(0 / 1)$ & $\begin{array}{l}.551 \\
(.498)\end{array}$ & $\begin{array}{l}-.087 \\
(.119)\end{array}$ & $\begin{array}{l}.018 \\
(.127)\end{array}$ & $\begin{array}{c}.002 \\
(.129)\end{array}$ & .001 \\
\hline Head: Age & $\begin{array}{c}45.3 \\
(16.7)\end{array}$ & $\begin{array}{l}-.011 " \\
(.006)\end{array}$ & $\begin{array}{l}-.014 * \\
(.006)\end{array}$ & $\begin{array}{l}-.015 * \\
(.006)\end{array}$ & -.006 \\
\hline Town $<20,000$ inhabitants $(0 / 1)$ & $\begin{array}{l}.305 \\
(.461)\end{array}$ & $\begin{array}{c}.293 " \\
(.163)\end{array}$ & $\begin{array}{l}.345 * \\
(.154)\end{array}$ & $\begin{array}{l}.401 * \\
(.172)\end{array}$ & .150 \\
\hline City > 100,000 inhabitants $(0 / 1)$ & $\begin{array}{l}. .453 \\
(.498)\end{array}$ & $\begin{array}{l}-.118 \\
(.142)\end{array}$ & $\begin{array}{l}-.030 \\
(.147)\end{array}$ & $\begin{array}{l}.059 \\
(.161)\end{array}$ & .023 \\
\hline Household in East Germany $(0 / 1)$ & $\begin{array}{l}.118 \\
(.322)\end{array}$ & $\begin{array}{l}.173 \\
(.199)\end{array}$ & $\begin{array}{l}.235 \\
(.203)\end{array}$ & $\begin{array}{l}-.065 \\
(.606)\end{array}$ & -.025 \\
\hline Children < age 16 in household $(0 / 1)$ & $\begin{array}{c}.388 \\
(.488)\end{array}$ & $\begin{array}{l}-.248 " \\
(.150)\end{array}$ & $\begin{array}{l}-.726 * * \\
(.149)\end{array}$ & $\begin{array}{l}-.727 * * \\
(.151)\end{array}$ & -.279 \\
\hline Constant & - & $\begin{array}{l}1.735 * * \\
(.273)\end{array}$ & $\begin{array}{l}2.274 * * \\
(.308)\end{array}$ & $\begin{array}{l}2.337 \text { ** } \\
(.315) \\
\end{array}$ & - \\
\hline State Fixed Effects & - & no & no & yes & - \\
\hline Number of observations & 740 & 740 & 740 & 740 & - \\
\hline Log likelihood & - & -331.85 & -305.41 & -300.19 & - \\
\hline
\end{tabular}


Table 5: continued

Note: 1) Columns (1) through (3) describe alternative specifications. Presented are coefficient estimates with standard errors in parentheses. **,*," indicate statistical significance at the 1 , 5 , and 10 percent level respectively. The standard errors are Huber-White corrected. The estimation is performed on unweighted data.

2) Specification (3) controls for state fixed effects which are not presented.

3) The last column describes the marginal effects of the covariates based on specification (3). For the continuous explanatory variables (poverty degree and age of household head) the effect is calculated as the change in the probability of non take-up following an infinitesimal change in the explanatory variable; for the remaining dichotomous measures the marginal effect describes the discrete change in the probability after the indicator variable takes on the values 0 or 1 .

Figure 1: Development of Standard Rate Benefits Over Time

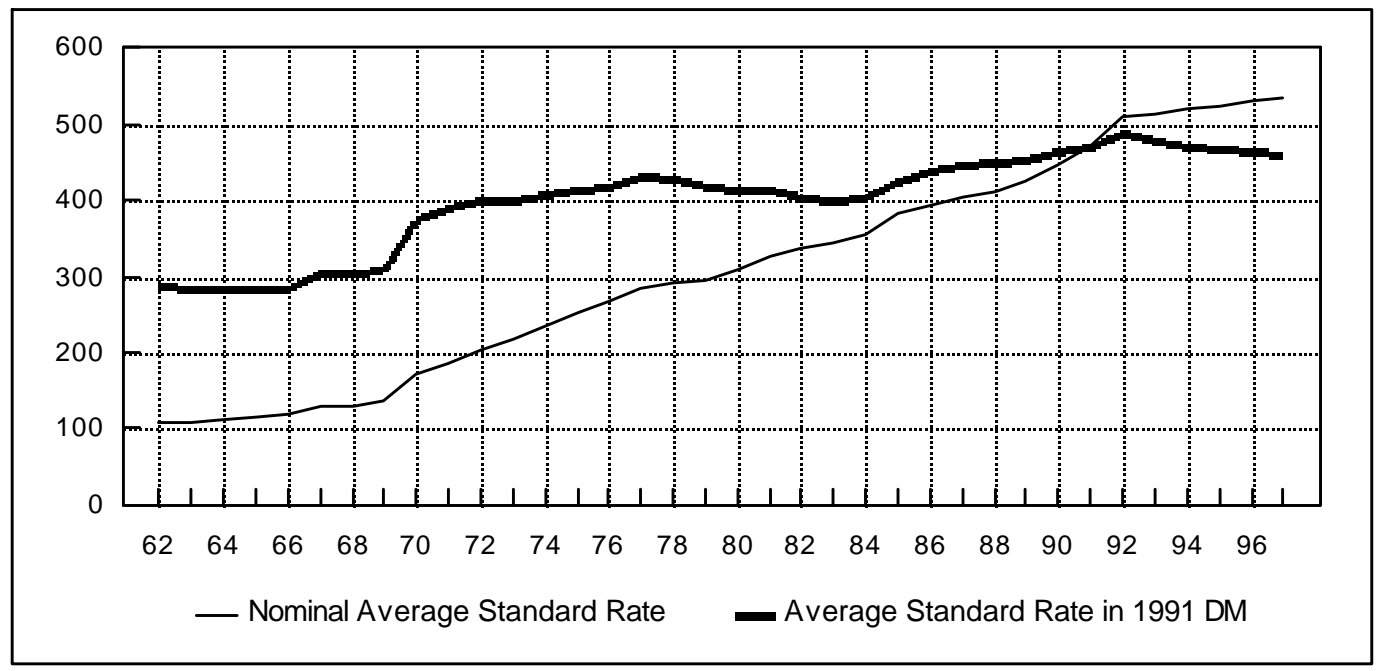

Source: Standard Rates: Nachrichtendienst des Deutschen Vereins für Private und Öffentliche Fürsorge (various years).

Consumer Price Index: Sachverständigenrat zur Begutachtung der gesamtwirtschaftlichen Entwicklung, Jahresgutachten, various years. 


\section{IZA Discussion Papers}

No. Author(s)

21
J. Ondrich
C. K. Spiess
Q. Yang
G. G. Wagner

22
A. Million
R. Rotte
K. F. Zimmermann

23

T. Bauer

K. F. Zimmermann

24 K. F. Zimmermann

M. C. Burda

J. von Hagen

K. Konrad

F. Schneider

G. G. Wagner

K. Papps

R. Winkelmann

26

D. Enste

F. Schneider

27

E. Bratberg

$\varnothing$. A. Nilsen

28

U. Broll

K. P. Wong

D. J. Snower

30

J. Kluve

H. Lehmann

C. M. Schmidt

31

C. M. Schmidt

32

S.- A. Dahl

$\varnothing$. A. Nilsen

K. Vaage

A. Lindbeck

D. J. Snower

34
Title

Area

Date

The Liberalization of Maternity Leave Policy and

$1 / 3$

9/98

the Return to Work after Childbirth in Germany

The Economics of Hospital Trips and Health Care 3

$9 / 98$

Reform

Learning Efficiency of Economics Students

7

$9 / 98$

Petersberger Erklärung: Anstöße für eine

$1 / 3$

$10 / 98$

zukunftsgerichtete Arbeitsmarktpolitik

Unemployment and Crime: New Answers to an

Old Question

Increasing Shadow Economies All Over the

World - Fiction or Reality?

Transitions from School to Work: Search Time and Job Duration

Efficiency Wages and Futures Markets

$1 / 7$

$1 / 99$

Causes of Changing Earnings Inequality

Active Labor Market Policies in Poland:

$1 / 99$

Human Capital Enhancement, Stigmatization or Benefit Churning?

Persistence and the German Unemployment

Problem: Empirical Evidence on German Labor Market Flows

Work or Retirement? Exit Routes for Norwegian Elderly

Price Dynamics and Production Lags 
Is Job Stability in the United States Falling?

Reconciling Trends in the Current Population

1

Survey and Panel Study of Income Dynamics

The Effects of European Economic and Monetary

Union on Wage Behaviour

37 H. S. Buscher

Exchange Rate Volatility Effects on the German

Job Satisfaction within the Scottish Academic

Multi-Task Learning and the Reorganization of

Work

Empirical Findings on the Swiss Migration

Anatomy of Policy Complementarities

Household Characteristics, Ability and Education: Evidence from a Dynamic Expected Utility Model

The Effects of Development on Migration:

Theoretical Issues and New Empirical Evidence

Tenure-based Wage Setting

Overtime Work and Overtime Compensation in Germany

51 A. Barrett

P. J. O'Connell
J. Mayer
R. T. Riphahn

Ethnic German Migration After 1989 - Balance and Perspectives

Does Training Generally Work?

The Returns to In-Company Training

Fertility Assimilation of Immigrants: Evidence from Count Data Models

Inter-industry Wage Dispersion in Portugal: high 7 but falling 


\begin{tabular}{|c|c|c|c|c|}
\hline 55 & L. Goerke & $\begin{array}{l}\text { Value-added Tax versus Social Security } \\
\text { Contributions }\end{array}$ & 3 & $8 / 99$ \\
\hline 56 & $\begin{array}{l}\text { A. Lindbeck } \\
\text { D. J. Snower }\end{array}$ & $\begin{array}{l}\text { Centralized Bargaining and Reorganized Work: } \\
\text { Are they compatible? }\end{array}$ & $1 / 5$ & 9/99 \\
\hline 57 & $\begin{array}{l}\text { I. N. Gang } \\
\text { K. F. Zimmermann }\end{array}$ & $\begin{array}{l}\text { Is Child like Parent? } \\
\text { Educational Attainment and Ethnic Origin }\end{array}$ & 1 & $9 / 99$ \\
\hline 58 & $\begin{array}{l}\text { T. Bauer } \\
\text { K. F. Zimmermann }\end{array}$ & Occupational Mobility of Ethnic Migrants & 1 & 9/99 \\
\hline 59 & $\begin{array}{l}\text { D. J. DeVoretz } \\
\text { S. A. Laryea }\end{array}$ & $\begin{array}{l}\text { Canadian Immigration Experience: } \\
\text { Any Lessons for Europe? }\end{array}$ & $1 / 2 / 3$ & 9/99 \\
\hline 60 & $\begin{array}{l}\text { C. Belzil } \\
\text { J. Hansen }\end{array}$ & $\begin{array}{l}\text { Subjective Discount Rates, Intergenerational } \\
\text { Transfers and the Return to Schooling }\end{array}$ & 7 & $10 / 99$ \\
\hline 61 & R. Winkelmann & Immigration: The New Zealand Experience & 7 & $10 / 99$ \\
\hline 62 & A. Thalmaier & $\begin{array}{l}\text { Bestimmungsgründe von Fehlzeiten: Welche } \\
\text { Rolle spielt die Arbeitslosigkeit? }\end{array}$ & 3 & $10 / 99$ \\
\hline 63 & M. Ward & Your Everyday, Average Academic & 5 & $10 / 99$ \\
\hline 64 & M. Ward & $\begin{array}{l}\text { Salary and the Gender Salary Gap in the } \\
\text { Academic Profession }\end{array}$ & 5 & $10 / 99$ \\
\hline 65 & $\begin{array}{l}\text { H. Lehmann } \\
\text { J. Wadsworth } \\
\text { A. Acquisti }\end{array}$ & $\begin{array}{l}\text { Grime and Punishment: Job Insecurity and Wage } \\
\text { Arrears in the Russian Federation }\end{array}$ & 4 & $10 / 99$ \\
\hline 66 & $\begin{array}{l}\text { E. J. Bird } \\
\text { H. Kayser } \\
\text { J. R. Frick } \\
\text { G. G. Wagner }\end{array}$ & $\begin{array}{l}\text { The Immigrant Welfare Effect: Take-Up or } \\
\text { Eligibility? }\end{array}$ & 3 & $10 / 99$ \\
\hline 67 & $\begin{array}{l}\text { R. T. Riphahn } \\
\text { A. Thalmaier }\end{array}$ & $\begin{array}{l}\text { Behavioral Effects of Probation Periods: } \\
\text { An Analysis of Worker Absenteeism }\end{array}$ & $1 / 3$ & $10 / 99$ \\
\hline 68 & B. Dietz & $\begin{array}{l}\text { Ethnic German Immigration from Eastern Europe } \\
\text { and the former Soviet Union to Germany: the } \\
\text { Effects of Migrant Networks }\end{array}$ & 1 & $11 / 99$ \\
\hline 69 & M.-S. Yun & $\begin{array}{l}\text { Generalized Selection Bias and the Decomposition } \\
\text { of Wage Differentials }\end{array}$ & 7 & $11 / 99$ \\
\hline 70 & $\begin{array}{l}\text { I. N. Gang } \\
\text { F.L. Rivera-Batiz }\end{array}$ & $\begin{array}{l}\text { Immigrants and Unemployment in the European } \\
\text { Community }\end{array}$ & 1 & $11 / 99$ \\
\hline 71 & L. Goerke & The Wedge & 3 & $11 / 99$ \\
\hline 72 & $\begin{array}{l}\text { J. Fersterer } \\
\text { R. Winter-Ebmer }\end{array}$ & $\begin{array}{l}\text { Are Austrian Returns to Education Falling Over } \\
\text { Time? }\end{array}$ & 7 & $11 / 99$ \\
\hline 73 & $\begin{array}{l}\text { G. S. Epstein } \\
\text { S. Nitzan }\end{array}$ & The Endogenous Determination of Minimum Wage & 3 & $11 / 99$ \\
\hline
\end{tabular}


Knowing What Works: The Case for Rigorous

Entry Decision into Self-Employment from Transition Economies

80 J. C. van Ours

The Netherlands: Old Emigrants - Young 
An Evaluation of Public Employment Programmes in the East German State of Sachsen-Anhalt

97 A. Barrett

L. Husted

H. S. Nielsen

M. Rosholm

N. Smith

102 B. van der Klaauw

J. C. van Ours

K. Brännäs

104

S. Kohns

105
G. Brunello
C. Graziano
B. Parigi

106
L. Bellmann
S. Bender
U. Hornsteiner

107 J. C. van Ours

G. Ridder

108 J. Boone

J. C. van Ours

109 G. J. van den Berg

B. van der Klaauw

D. DeVoretz

C. Werner
Irish Migration: Characteristics, Causes and 1 Consequences

Industry Wage Differentials Revisited: A

Longitudinal Comparison of Germany and USA

Residential Location and Youth Unemployment:

\section{Transitions}

Immigrant Assimilation and Welfare Participation: 1/3/7

Do Immigrants Assimilate Into or Out-of Welfare?

Employment and Wage Assimilation of Male First 3 Generation Immigrants in Denmark

Estimation in a Duration Model for Evaluating

Different Skill Levels and Firing Costs in a

Matching Model with Uncertainty -

An Extension of Mortensen and Pissarides (1994)

Ownership or Performance: What Determines

Board of Directors' Turnover in Italy?

Job Tenure of Two Cohorts of Young German Men
1979 - 1990: An analysis of the (West-)German Employment Statistic Register Sample concerning multivariate failure times and unobserved heterogeneity

Fast Track or Failure: A Study of the Completion Rates of Graduate Students in Economics

Modeling Financial Incentives to Get Unemployed

Back to Work

Combining Micro and Macro Unemployment 
K. Terrell

112 L. Bellmann

T. Schank

113 R. Euwals

114 G. Brunello

A. Medio

115 A. Cigno

F. C. Rosati

116 C. Belzil

117 S. Bender

A. Haas

C. Klose

118 M. A. Shields

M. E. Ward

119 A. Lindbeck

D. J. Snower

120 P. T. Pereira

P. S. Martins

121

J. C. van Ours

122

D. Munich

J. Svejnar

K. Terrell

123 J. Hunt

124 R. T. Riphahn
Sectoral Restructuring and Labor Mobility:

A Comparative Look at the Czech Republic

Innovations, Wages and Demand for

Heterogeneous Labour: New Evidence from a

Matched Employer-Employee Data-Set

Do Mandatory Pensions Decrease Household

Savings? Evidence for the Netherlands

An Explanation of International Differences in

Education and Workplace Training

Why do Indian Children Work, and is it Bad for

Them?

Unemployment Insurance and Subsequent Job

Duration: Job Matching vs. Unobserved

Heterogeneity

IAB Employment Subsample 1975-1995.

Opportunities for Analysis Provided by the

Anonymised Subsample

Improving Nurse Retention in the British National

Health Service: The Impact of Job Satisfaction on

Intentions to Quit

The Division of Labor and the Market for

Organizations

Does Education Reduce Wage Inequality?

Quantile Regressions Evidence from Fifteen

European Countries

Do Active Labor Market Policies Help Unemployed $\quad 4 / 6 \quad 3 / 00$

Workers to Find and Keep Regular Jobs?

Returns to Human Capital under the Communist

Wage Grid and During the Transition to a Market

Economy

Why Do People Still Live in East Germany?

Rational Poverty or Poor Rationality? The Take-up 3 of Social Assistance Benefits
5

$2 / 00$

$3 / 00$

$1 / 4$

$2 / 00$

5

$2 / 00$

$2 / 00$

$2 / 00$

$2 / 00$

$2 / 00$

$2 / 00$

5

$2 / 00$

$5 / 7 \quad 2 / 00$

4

$3 / 00$

$3 / 00$

An updated list of IZA Discussion Papers is available on the center's homepage www.iza.org. 